\title{
Is Clinical Engineering an occupation or profession?
}

\author{
By Y. David ${ }^{1}$, S. Calii ${ }^{2}$, N. Pallikarakis ${ }^{3}$, M. Poluta ${ }^{4}$, S.Bergamasco ${ }^{5}$, D. Clark ${ }^{6}$, T. Judd ${ }^{7}$, J. Wear ${ }^{8}$, K. Fukuta ${ }^{9}$, S. Mullaly ${ }^{10}$, W. Morse ${ }^{11}$ \\ ${ }^{1}$ Global Clinical Engineering Summit Chairman, USA \\ ${ }^{2}$ Clinical Engineering Professor, Brazil \\ ${ }^{3}$ Chairman of the Institute of Biomedical Technology, Greece \\ ${ }^{4}$ Clinical Engineer, South Africa \\ ${ }^{5}$ Italian Clinical Engineers Association (AIIC), Italy \\ ${ }^{6}$ Clinical Engineering, Nottingham University Hospitals NHS Trust, UK \\ 7 IFMBE/Clinical Engineering Division Chairman, USA \\ ${ }^{8}$ Clinical Engineering Consultant, USA \\ ${ }^{9}$ Clinical engineer lecturer at Osaka University, Japan \\ ${ }^{10}$ Biomedical Engineer at Consultant, Ottawa, Ontario, Canada \\ ${ }^{11}$ Founding member of ACCE and President in Bellegrove Medical, USA
}

\begin{abstract}
In this paper, we examine the practice level of engineers and discuss whether Clinical Engineering is a profession or an occupation. Many think that occupation and profession are synonyms, but are they? One must explore the difference, if it exists, between these terms, and to accomplish that, clarification of these terms is being offered and established first. We conducted a review of the terms and proceeded to identify if the tenants that are expected to be associated with professional standing are included in applying clinical engineering practices and to what level if it is. Engineering is a profession that improves the quality of living and for the common good. The professional education of engineers requires the education to contain a body of specialized knowledge, problem-solving skills, ethical behavior, and good analytical judgment in the service of all people. The engineering education domains aim to form individuals who are intellectually trained, practically adept, and ethically accountable for their work. Especially within the healthcare delivery system, engineering work engages problem-solving dependent upon sufficient body of knowledge to deal with practical problems by understanding the why, knowing how and identifying the when. There are various levels of the expected body of knowledge within the clinical engineering field ranging from engineers with formal academic training at undergraduate and graduate levels to clinical engineering technologists and technicians having graduated from between 1-4 years of academic training. Engineers may further select to publicly proclaim their adequate preparation and mastering of knowledge to conduct their work through a credentialing process that can confer the term professional, registered, or certified engineer if successfully achieved. Once the differences of working characteristics and obligations between occupation and profession are understood, it is clear that clinical engineers must continuously commit to pursue and fulfill these obligations. Therefore, every professional engineer is called on to achieve a certain degree of intellectual and technical mastery and acquire practical wisdom that brings together the knowledge and skills that best serve a particular purpose for the good of humanity. Clinical engineers and technologists are critical for sustaining the availability of safe, effective, and appropriate technology for patient care. It is as important for their associations to collaborate on compliance with professional obligations that their jobs require.
\end{abstract}

Keywords - Profession, Occupation, Vocation, Engineering, Clinical Engineering, credentialing, certification, Healthcare job, Qualification, Alliance, Engineer.

Copyright (c) 2021. This is an open-access article distributed under the terms of the Creative Commons Attribution License (CC BY): Creative Commons - Attribution 4.0 International - CC BY 4.0. The use, distribution or reproduction in other forums is permitted, provided the original author(s) and the copyright owner(s) are credited and that the original publication in this journal is cited, in accordance with accepted academic practice. No use, distribution or reproduction is permitted which does not comply with these terms. 


\section{INTRODUCTION}

To answer the question is Clinical Engineering an occupation or profession, one must explore the difference, if it exists, between these terms. An excellent point to begin is with a practical understanding of the task at hand, i.e., terminology. When humans spend time trying to achieve something, especially when this involves using some effort, it is called work. ${ }^{1}$ There are many different types of work. Occupation $^{2}$ is one of many types of work which one occupies oneself with; usually refers to productive activity, task, service, trade, or craft for which one is paid. It is of a long term, perhaps as long as a lifetime, and is a path one embarks upon to fulfill goals, passions, and or ambitions. Such a path is a career that requires a certain level of education or training preparation to achieve the goals and ambitions successfully. The benefits of pursuing a career are often associated with monetary, work satisfaction, personal pride, economic independence, become part of the community, and self-worth, to name a few of them. Throughout a person's career, they will probably hold several jobs ${ }^{3}$ or tasks identified as work performed to earn money to support basic needs and also help create relationships or develop a working network to advance one's career.

Many think that occupation and profession are synonyms, but the fact is that they are different. An Occupation is a work activity undertaken by a person to earn a living. It can be business, profession, or employment that a person undertakes to increase their wealth. Occupation refers to the kind of economic activity endeavored by a person regularly for earning money. When someone engages or occupies themselves in any economic activity, that activity is known as their occupation. An occupation does not necessarily require specialized schooling in a particular area and applies to any category of work that is consistently performed. An occupation includes jobs involving both physical work and mental effort. An occupation is a job that may include a profession which leads to most official forms using the term occupation when asking for an applicant's job or profession.

Examples of occupations include jobs such as vehicle drivers, shopkeepers, civil servants, clerks, bookkeepers. Occupations can be further divided into subcategories like:
- Business: A person engaged in any trade, commerce, or manufacturing activities, is assumed to be doing business.

- Employment: A type of occupation in which a person works for others, is being supervised, and gets a fixed and regular income.

- Profession: The type of occupation in which a person renders services to others and holds themselves out as an expert by applying his specific knowledge and skills is a profession.

The line of demarcation between occupation and profession exists but is blurred when given insufficient attention to the attributes that clarify the difference between these terms. For example, when a professional is paid for his skill or talent, it is known as an occupation. However, this represents more specific and different types of occupation when independent creative thinking, based on long and specific training, and compliance with achieving professional credentialing show the public achievement of practice competency we call a profession. Therefore, a profession is an occupation for which a person undergoes specialized training or internship to get a higher degree of education and expertise in the concerned area.

Profession $^{4}$ is an activity that requires specialized training, knowledge, qualification, and skills. It implies membership in a professional body, credentialing, and certificate of practice. The individuals who undertake a profession of rendering personalized services are called professionals, guided by a specific professional body code of conduct. A profession refers to specific categories of occupations that typically require advanced education or training and acquisition of the previous knowledge ${ }^{5}$ pertains to the research and practice of the field of study.

The main objective of the profession is to render services to those who need them. A professional body or statute governs the profession. To be called a professional, a person has to pursue higher studies and qualify for an exam conducted by the governing body. Typically, a professional is said to be an expert in the field. In addition, the professional body develops ethical codes that the professionals must follow to ensure uniformity in their work. 
The primary feature of any profession is the special relationship between the profession and the society and the commitment to serve responsibly, selflessly, and wisely. At times, this can create tension between the two elements of professional responsibility: the duty to serve the interests of one's immediate client and the obligation one has to society. Examples for profession include jobs like medical doctors, architects, lawyers, chartered accountant, clergy, nursing, and engineers, "At present, few would dispute the claim that physicians, lawyers, architects, accountants, engineers, and clergy are professionals."

It is helpful at this juncture to point to what are the major differences between occupation and profession.

1. Unlike an occupation, a profession has an expected code of conduct.

2. An occupation does not require lengthy training in a particular field, but a profession requires specialized training in a specific area.

3. In general, the practice in a profession is regulated by a particular or professional body statute while an occupation is not.

4. A person with an occupation is paid for what he produces. Whereas in a profession, one gets paid according to his knowledge and expertise.

5. The profession is also an occupation when the person is paid for utilizing his skills and expertise.

6. A professional is independent, and any external force does not influence their work. However, conversely, there is a lack of independence in an occupation because the person performing it has to follow the commands of his supervisors.

7. Some conduct responsibilities are associated with the practice of a profession. However, an occupation does not have such responsibilities.

8. The basic pay in a profession usually is higher than in an occupation.

9. Professionals are usually respected more by people and have a higher status in society than those in an occupation.

\section{EVOLUTION OF OTHER PROFESSIONS}

Few practice fields are accepted as professions. ${ }^{7}$ Some more than others. These include, for example, medicine, law, and nursing. The nursing field went through a developmental evolution of its profession following the challenge such as described in an article published by the New York Medical Journal stating that nursing is not a profession since "... it is not primarily designed to contribute to the sum of human knowledge or the advancement of science." ${ }^{8}$ The response from the nursing field was clear: "With all due respect to the New York Medical Journal, nursing today does require, not only skill and intelligence but education. It is true that there are many mechanical duties in a nurse's life which require only skill but to be an efficient nurse demands also special knowledge and attainments. We have only to look backward a little over a century to notice how education, special knowledge and attainments in nursing affairs have changed the whole system of nursing." ${ }^{8}$ The medical profession today is also facing a challenge with the extent of the regulatory nature of the profession, which is critical to the consideration of its professional standing. ${ }^{9}$ In medicine, the regulation is practiced at several levels: medical schools must adhere to a standard, licensure as a process at the state level. At the same time, certification is administered through national organizations adopting a minimal level of professional practice requirements and standards. "Most doctors will find a way round this new regime, but short-term pettyminded bosses are beginning to view doctors as factory workers. Their limited vision considers doctors to be dangerously independent, malfunctioning cogs in their wobbly healthcare machine, a species to be controlled and beaten into the shape of the appropriate widget."10

The medical profession: "A vocation characterized by a specialized body of knowledge of medicine that its members must teach and expand, by a code of ethics and a duty of service that put patient care above self-interest, and by the privilege of self-regulation granted by society."11 This establishes a career in medicine as one of the oldest and most respected professions; it affords the potential to impact human life genuinely and is usually associated with a high level of job satisfaction. 


\section{ENGINEERING AND ENGINEERS}

Like medicine, in engineering, public health, safety, and welfare tasks are expected to be protected from unintended consequences. As shown in a public survey following the fatality caused by an UBER autonomous car accident, public distrust follows public harm. The survey showed that trust in such vehicles dropped by $27 \%{ }^{12}$ following increased perception of insufficient harm control. Other disasters show a similar trust impact, for example, following the space shuttle explosion after lift-off. ${ }^{13}$

Under the practice of engineering's obligation to public health, safety, and welfare, it is critical to understand what engineering is. Engineering is defined as the "application of science and mathematics to solve problems useful to people."14 The practice of engineering is defined as "any service or creative work requiring engineering education, training, and experience in the application of engineering principles and the interpretation of engineering data to engineering activities that potentially impact the health, safety, and welfare of the public." ${ }^{15}$ Engineers are practitioners of material products of human making just as physicians are practitioners of medicine. ${ }^{16}$ An engineer is defined as "an individual who is qualified to practice engineering by reason of engineering education, training, and experience in the application of engineering principles and the interpretation of engineering data." ${ }^{17}$ And Professional Engineer means "an individual who has been duly licensed as a professional engineer by the board. The board may designate a professional engineer, on the basis of education, experience, and examination, as being licensed in a specific discipline or branch of engineering signifying the area in which the engineer has demonstrated competence." ${ }^{17}$

Professions lay claim to a theoretical knowledge base such as a body of research, conceptions, and experience thresholds for its services. Whether that knowledge base is a body of biomedical or clinical research and theory, a collection of published manuscripts, or a body of laws, regulations, and legal decisions, professions rest much of their authority on the knowledge accumulated during the practice of the profession. This is one of the challenges clinical engineering faces-a lack of sufficient academic preparation programs and uniformity of public expectations from practicing engineers.
One of the fundamental pillars on which a profession stands is the mastery of a domain of practice. The technical skills of analysis and presentation of a solution or treatment, the practice of diagnosis, action, and interaction are all features of any profession. A profession is identifiable by the very practices in which its members engage. Professions rest much of their authority on the knowledge that their domain develops together with the profession's practice and higher education academic programs. During professional education and through the engineer's career, the practicing professional is expected to remain current with the growth and changes in that knowledge base and establish a threshold for demonstration of competent practice. $^{18}$

Professional practice can be routine at times. However, challenges during professional practice are the need to make complex judgments and decisions leading to skilled actions, sometimes under uncertain conditions. This means that professional practice is frequently pursued at or beyond the margins of previously learned performances. Therefore, professionals must be appropriately trained to operate at the uncertain limits of their previous experience and must also be prepared to learn from the consequences of their actions to develop new understandings and better routines. Hand in hand, professional engineers must engage in exchanging those understandings with other professionals so the entire professional community benefits from their insight. Such an engagement is another deficiency in clinical engineering practitioners lacking the motivation and the available opportunities to publish their lessons learned. This is one of the profession's characteristics of learning from one's experience to improve future outcomes and create better-skilled practitioners. The conditions of professional practice and professional learning demand the establishment of and cross-functioning between professional communities. In addition to knowledge, the engineering profession should also teach their practitioners how to be a member of a professional community, with obligation for establishing and renewing thresholds for both practice and professional education, for critically reviewing new ideas, methods, and techniques, and disseminating it within the community of practice, for overseeing the quality of performances at all stages of engineer's career, and for contributing back to the community where they live. 


\section{CLINICAL ENGINEERING PRACTICE}

Engineering is, at its core, problem-solving. Being an engineer means being a problem solver, capable of diagnosing, analyzing a situation, and finding a solution within a set of constraints even if it is not optimal. Similarly, one of the most required skills to be a clinical engineer is to solve problems quickly. ${ }^{19}$ Also needed is the capacity to formulate the problem in technical and non-technical ways and partition the problem into subparts to achieve a satisfactory and safe resolution., Clinical engineers are uniquely prepared to accomplish this task ${ }^{20}$ and determine the requirements and constraints while applying varied knowledge and experience to reach a timely, optimal resolution. Such an approach depends on knowledge and analysis of the state of specific phases in the technology lifecycle, non-compliance issues, risk tolerance management, user's competence, system integration impact, or financial analysis, all in a short duration. Perhaps faster than in the other professions we discussed earlier, the knowledge that a clinical engineer draws from is continually expanding and evolving because of the technological evolution and clinical practice itself. As outlined in the article The Professional Clinical Engineer, ${ }^{21}$ there are common characteristic considered stewardship of all professions: a commitment to serve in the interests of specific clients and the general welfare of humankind; a body of knowledge and principles; a required specialized set of skills, practices, and performances unique to the profession; the capacity to render judgments ethically and with integrity under uncertain conditions; a commitment to engage in continuing education and learning attitude to absorb new knowledge from the contexts of practice; and the development of a professional community responsible for the oversight and monitoring of quality in both practice and professional education. Clinical engineers are mostly reflective, alert, and methodical as they carry out their clinical engineering projects, hopefully making their wider professional community better practitioners at the end of the project. A recent international survey ${ }^{22}$ about the body of knowledge (BoK) and body of practice (BoP) practiced by clinical engineering practitioners demonstrate international variability in the definition of the practice domain with new knowledge subjects added during the last 25 years, such as technology assessment and forensic analysis. The majority of the clinical engineers who responded to the survey were employed within the healthcare delivery system. This population demonstrated that common domain elements across the world exist both in the BoK required to practice and in the BoP performed. Having identifiable domain boundaries is an essential characteristic of a profession, and this survey and others ${ }^{23}$ support compliance of the clinical engineering field with this requirement.

Goodman argued that clinical engineering is a profession embarking on an identified path of: "The progress of an occupation toward professionalization involves: the

TABLE 1. Comparison between job characteristics.

\begin{tabular}{|c|c|c|c|}
\hline Basis for Comparison & Occupation & Profession & Clinical Engineering \\
\hline Meaning & $\begin{array}{c}\text { Occupation refers to the } \\
\text { regular activity performed by } \\
\text { a person to earn a living }\end{array}$ & $\begin{array}{c}\text { A profession is an occupation or vocation } \\
\text { which requires academic preparation for } \\
\text { knowledge and expertise in the specific field }\end{array}$ & $\begin{array}{c}\text { Requires a degree of } \\
\text { knowledge and expertise in } \\
\text { the specific field }\end{array}$ \\
\hline Code of Conduct & No & Yes & Partial \\
\hline Training & Not necessary & Compulsory & Necessary \\
\hline Regulated by Statute & No & Skill and Knowledge & Skill and Knowledge \\
\hline Basis of pay & Produce & Yes & Not compulsory \\
\hline Higher Education & Not compulsory & A profession is completely independent & Some degree of independence \\
\hline Degree of Independence & independence & Yes & Yes \\
\hline Responsibilities & Very limited & Very high & Partially \\
\hline Respect and status & Low & & \\
\hline
\end{tabular}


appearance of training schools; establishment of university educational programs; licensure or certification; a formal code of ethics; and establishment of one or more national professional associations." ${ }^{24} \mathrm{He}$ further supports his argument by showing a BoK, a structured educational system, and professional organization representing them in the healthcare field.

\section{DISCUSSION}

The U.S. Department of Labor describes engineering as applying "the theory and principles of science and mathematics to research and develop economical solutions to technical programs. [This work] is the link between perceived social needs and commercial applications." 25 This site continues to identify that "Engineering fields can be practiced at the associate degree level include electrical and electronics drafters, civil engineering technicians, and aerospace operations technicians. However, a bachelor's degree is needed for civil, electrical, and mechanical engineering, as well as the less commonly known engineering fields in aerospace, biochemical, energy, industrial, robotics, marine engineering, and naval architecture." In furthering narrowing the career's focus this source reports on bioengineers and biomedical engineers jobs (there is no category to be found for clinical engineers) as required to "Apply knowledge of engineering, biology, chemistry, computer science, and biomechanical principles to the design, development, and evaluation of biological, agricultural, and health systems and products, such as artificial organs, prostheses, instrumentation, medical information systems, and health management and care delivery systems." ${ }^{26}$ Having typical job duties that are, in most part, similar to yet not the same as clinical engineer's job.

- Conduct research, along with life scientists, chemists, and medical scientists on the engineering aspects of the biological systems of humans and animals.

- Adapt or design computer hardware or software for medical science use.

- Evaluate the safety, efficiency, and effectiveness of biomedical equipment.

- Develop models or computer simulations of human biobehavioral systems to obtain data for measuring or controlling life processes.
- Research new materials to be used for products, such as implanted artificial organs.

- Write documents describing protocols, policies, standards for use, maintenance, and repair of medical equipment.

- Conduct training or in-services to educate clinicians and other personnel on the proper use of equipment.

- Analyze new medical procedures to forecast likely outcomes.

- Advise hospital administrators on the planning, acquisition, and use of medical equipment.

Table 2 below, articulate few of the shared as well as the different duties between Biomedical Engineer and Clinical Engineer professions.

On the other hand, in addressing the question "What is engineering practice?" in a less detailed and more generalized picture of the work, we also need to consider whose point of view is expressed in the answer. One group is individuals and organizations engaged in engineering work based on, for example, surveys and interviews of practicing engineers. Alternatively, there is the view offered by researchers observing the work of engineers, then synthesize these observations into patterns and a more generalized understanding of the nature of engineering practice. Alternatively, yet still, there is the view that may be offered by those engaged in engineering education, namely engineering faculty and students. These view angles will produce the following answers: engineering is problem-solving, considering the systematic processes that engineers use to define and resolve problems; engineering is knowledge, considering the specialized knowledge that enables or fuels the process; engineering is the integration of process and knowledge. All are acceptable descriptions for the practice of engineering.

Critical differentiators between an occupation and a profession are whether or not members of the field, in our case clinical engineers, having attributes such as:

(1) a BoK with high degree of systematic continuous training,

(2) mastery of their domain,

(3) commitment to selflessly and ethically serve,

(4) ability to render professional judgement, and 
(5) Self-governance by monitoring the quality-of-service members provide through a credentialing program. According to the US National Society of Professional Engineers (NSPE) ${ }^{27}$ the practice of engineering is a professional service regulated by each of the States' governments that in the USA is governed by the first engineering licensure $l^{2} w^{28}$ enacted in 1907 "to ensure public safety by granting only Professional Engineers (PEs) the authority to sign and seal engineering plans and offer their services to the public." This is an example of one of the profession's attributes, self-governance of service quality through a credentialing program. Following licensure as a professional engineer, individuals may voluntarily have their expertise in a specified field of engineering recognized through an appropriate specialty certification program. Such certification does not imply that other licensed professional engineers are less qualified for practice in their particular field of specialty.

TABLE 2. Comparison of job duties between Biomadical and Clinical Engineer.

\begin{tabular}{|c|c|}
\hline Biomedical Engineer & Clinical Engineer \\
\hline $\begin{array}{l}\text { Conduct research, along with life scientists, chemists, and other } \\
\text { medical scientists, on the engineering aspects of the biological } \\
\text { systems of humans and animals }\end{array}$ & - \\
\hline $\begin{array}{l}\text { Evaluate the safety, efficiency, and effectiveness of biomedical } \\
\text { equipment }\end{array}$ & $\begin{array}{l}\text { Evaluate the safety, efficiency, and effectiveness of biomedical } \\
\text { equipment }\end{array}$ \\
\hline $\begin{array}{l}\text { Research new materials to be deployed in products, such as } \\
\text { implanted artificial organs }\end{array}$ & - \\
\hline $\begin{array}{l}\text { Conduct training or in-services to educate clinicians and other } \\
\text { personnel on proper use of equipment }\end{array}$ & $\begin{array}{c}\text { Conduct training or in-services to educate clinicians and other } \\
\text { personnel on proper use of equipment. }\end{array}$ \\
\hline $\begin{array}{l}\text { Advise hospital administrators on the planning, acquisition, and } \\
\text { use of medical equipment }\end{array}$ & $\begin{array}{c}\text { Advise hospital administrators on the planning, acquisition, } \\
\text { and use of medical equipment. }\end{array}$ \\
\hline $\begin{array}{l}\text { Adapt or design computer hardware or software for application in } \\
\text { medical science uses }\end{array}$ & $\begin{array}{l}\text { Adapt or design computer hardware or software for application in } \\
\text { medical science uses }\end{array}$ \\
\hline $\begin{array}{c}\text { Develop models or computer simulations of human } \\
\text { biobehavioural systems to obtain data for measuring or controlling } \\
\text { life processes }\end{array}$ & - \\
\hline $\begin{array}{c}\text { Create guidelines, documents describing protocols, policies, } \\
\text { standards for use, maintenance, testing and repair of medical } \\
\text { equipment }\end{array}$ & $\begin{array}{c}\text { Create guidelines, documents describing protocols, policies, } \\
\text { standards for use, maintenance, testing and repair of medical } \\
\text { equipment }\end{array}$ \\
\hline $\begin{array}{l}\text { Analyse new technology-based medical procedures to forecast } \\
\text { likely outcomes }\end{array}$ & $\begin{array}{l}\text { Analyse new technology-based medical procedures to forecast } \\
\text { likely outcomes }\end{array}$ \\
\hline- & $\begin{array}{l}\text { Manage Medical devices performance assurance program (i.e. } \\
\text { Maintenance) }\end{array}$ \\
\hline- & $\begin{array}{l}\text { Design, Implement, monitor, and manage healthcare technology } \\
\text { Safety Program }\end{array}$ \\
\hline- & $\begin{array}{l}\text { Design, Implement, and monitor a Service Contract Management } \\
\text { System }\end{array}$ \\
\hline Most job duties performed in research laboratories & Most job duties are performed at the point of care \\
\hline- & $\begin{array}{l}\text { Apply Forensic Engineering, Health Technology Assessment, } \\
\text { Disaster Preparedness, and Human Factor Engineering principles }\end{array}$ \\
\hline- & $\begin{array}{l}\text { Operate at the point of care complex healthcare systems in selected } \\
\text { countries }\end{array}$ \\
\hline
\end{tabular}


Professional engineering licensure, in several countries, is the only qualification for engineering practice. A less successful example but yet crucial for the clinical engineering profession debate was documented by the World Health Organization (WHO) summarizing the work of a task force on Manpower Development for a Health Care Technical Service ${ }^{29}$ where the minimum qualifications for a Clinical Engineer I states "Must be willing to work towards becoming a Certified Clinical Engineer." Moreover, Clinical Engineer II states, "Clinical Engineering certification and/or professional engineering registration are required." So far, these recommendations have not shown significant impact on the concept of adopting selfgovernance for clinical engineering practitioners. More substantial adoption will lead to more robust compliance with professional characteristics. It may now be better to initiate a new internationally coordinated effort to achieve broad adoption of this crucial professional trait. While credentialing is a program administered by a third party and is proof of an individual's qualification in a given subject, a certification program ${ }^{30}$ is a process that recognizes and validates an individual's qualification that is usually administered by the profession itself. Clinical engineering as a professional field will gain recognition through a better definition for practicing clinical engineers' minimum academic preparation requirements, increase compliance with a public declaration of practice proficiency (certification), commitment to continuing education, and adoption of expected ethical behavior. All of these cannons are already integral parts of the present Clinical Engineers' practice. It will gain further recognition when an international uniformity is adopted.

\section{CONCLUSION}

Following the above discussion, it can be said that the occupation is a broader term, and it includes profession. All work deserves respect, and while occupation includes ordinary jobs and hence does not receive high recognition from society, professionals are mainly known by the knowledge base required to provide their service and professional judgment as part of their jobs. They were perhaps suggesting that such contribution to society draws a higher level of respect and recognition.

A profession is usually a higher-order occupation or a calling, especially involving a high level of education, career long continuous training, formal credentialing, mastered knowledge domain, adoption of rules for ethical behavior, and self-governance monitoring program of its members. In general, we found that engineering education programs attempt to prepare graduates for professional engineering practice. The programs include elements that illustrate and teach engineering problem-solving skills, provide engineering graduates with competent technical and managerial skills, and provide cultural education in the humanities and social sciences. Societies of Professional engineers support the notion that engineering curricula must incorporate instruction designed to instill in engineering students the concepts of professionalism and the ethical practice of engineering. Engineering education is and should be a lifelong learning experience. The depth of engineering knowledge continues to expand rapidly, and practicing engineers must renew their knowledge to remain effective and competent. The portion of the lifelong learning experience that follows formal engineering education is referred to as continuing professional development and is one factor that establishes that one's occupation is a profession. However, to fully meet such a mandate, clinical engineers need to demonstrate more comprehensive global compliance. Academic institutions can support this by offering clinical engineering curricula and continuing education training opportunities for their graduates. At all of the engineering branches, the US NSPE supports the premise that, "the public interest is best served by the licensure of all qualified individuals within the engineering profession." Credentialing has many forms, and clinical engineering should be no exception.

Clinical engineers also need to recognize, like other professions that when establishing defined requirements to enter the professional practice, there needs to be consensus about and adopting clinical engineering practice criteria. This includes domain boundaries, establishing a minimum qualifications criterion for entering clinical engineering practice in healthcare, a commitment for compliance with life-long continuing education, adherence to ethical behavior, service stewardship to their communities, and rules for self-governing. Adoption of these cannons will gain wider recognition and elevate the professional standing they desire. We recommend that the Global Clinical Engineering alliance will best serve as a leader for collaboration between stakeholders such 
as academia, industry, healthcare providers, and government agencies. Working together to facilitate that clinical engineering practitioners deserve - be the engineering and technology professionals within the healthcare team.

\section{REFERENCES}

1. MacMillan Dictionary - Words Form, Definitions. Work. Available at: WORK (verb) definition and synonyms | Macmillan Dictionary

2. MacMillan Dictionary - Words Form, Definition, Occupation. Available at: OCCUPATION (noun) definition and synonyms | Macmillan Dictionary

3. MacMillan Dictionary - Words Form, Definitions, Job. Available at: JOB (noun) definition and synonyms | Macmillan Dictionary

4. MacMillan Dictionary - Words Form, Definitions, Profession. Available at: PROFESSION (noun) definition and synonyms | Macmillan Dictionary

5. National Council of Examiners for Engineering and Surveying (NCEES). Model Law. August 2006. Available at: http://ncees.org/wp-content/uploads/Model-Law.pdf

6. 6. Sheppard S, Colby A, MaCatangay K, and Sullivan $\mathrm{K}$. What is engineering practice? Int J Engng Ed 2006;22(3):429-38. Available at: https://www.ijee. ie.articles/vol22-3/02_ijee1751.pdf

7. Gardner HE, Shulman LS. The professions in America today. J Am Acad Arts Sci Daedalus 2005;1234(3)16. Available at: Daedalus_Su05_Professions-and-Professionals.pdf (amacad.org)

8. Messer MA. Is nursing a profession? Am J Nurs Vol 1914;15(2):122-25. Available at: https://www.jstor. org/stable/pdf/3404530.pdf

9. US National Library of Medicine, MedlinePlus: Doctor of Medicine. Available at: https://medlineplus.gov/ ency/article/001936.htm

10.Abbasi K. Is medicine still a profession?, J Royal Soc Med (JRSM) 2009;102(9)353.

11.Conrad M. MedTerms Medical Dictionary, MedicineNet WebMD, Stoppler; 2020; Available at: https://www. medicinenet.com/medical_profession/definition.htm
12.Smith A. Distrust in self-driving cars on the rise after crashes, CNN Business, May 23, 2018. Available at: https://money.cnn.com/2018/05/22/technology/ self-driving-cars-aaa/index.html

13. Britannica. Challenger Disaster, United States History. 1986. Available at https://www.britannica.com/event/ Challenger-disaster

14.Lucas J What is engineering? Types of engineering, [Internet] Life Sci 2014. Available at: https://www. livescience.com/47499-what-is-engineering.html

15. National Society of Professional Engineers. Defining the Practice of Engineering. 2018. Available at: https:// www.nspe.org/sites/default/files/resources/pdfs/ admin/publications/NSPE-PE-Definitions.pdf

16.McGinn RE. Science, Technology, and Society, Prentice Hall Foundation of Modern Sociology Series, Prentice Hall, New Jersey;1991.

17. National Society of Professional Engineers. What is PE? Availabe at: https://www.nspe.org/resources/licensure/ what-pe\#: :text=To\%20become $\% 20$ licensed $\% 2 \mathrm{C} \% 20$ engineers $\% 20$ must,from $\% 20$ their $\% 20$ state's $\% 20$ licensure $\% 20$ board.\&text=To\%20use $\% 20$ the $\% 20$ PE\%20seal,steps\%20to\%20ensure\%20their\%20 competency. (last visited May 25, 2021).

18. Wear JO. IFMBE/CED recognition of certification/registration programs for clinical engineering practitioners, Global Clin Eng J 2020;2(2). Available at: https://www. globalce.org/index.php/GlobalCE/article/view/79 (last visited May 26, 2021).

19.IFMBE/European Alliance for Medical and Biological Engineering \& Science. BIOMEDEA Draft Protocol for the Training of Clinical Engineers in Europe; 2005. (last visited May 26, 2021).

20.Inchingolo P. The Multi-level Education in Clinical Engineering of the University of Trieste, Biomedical Engineering Preparing for the European Higher Education Area (BIOMEDEA -3), Stuttgart, Germany, Sept 23-25, 2005.

21. David Y. The professional clinical engineer, J Clin Engineer 1988;13(5):345-46. Available at: https://www. 
researchgate.net/publication/302366037_The_Professional_Clinical_Engineer (last visited May 25, 2021).

22. Nascimento L, Calil S, Judd T, and David Y. Analysis of IFMBE-CED 2017 Worldwide Clinical Engineering Survey, Global Clin Engineer J 2019;2(1):15-22. Available at: View of Analysis of IFMBE-CED 2017 Worldwide Clinical Engineering Survey (globalce.org) (last visited May 25, 2021).

23. Navaro K, Iduri B, Brockway S, Syed R. ACCE 2018 Body of Knowledge survey results, MDExpo, Houston, Texas 2019. Available at: https://mdexposhow.com/ presentation/2018-acce-body-of-knowledge-boksurvey-results/ (last visited May 25, 2021).

24.Goodman G. The profession of clinical engineering. J Clin Engineer 1989;14(1):27-38. Available at: https:// journals.lww.com/jcejournal/Abstract/1989/01000/ The_Professio_of_Clinical_Engineering.8.aspx (last visited May 25, 2021).

25.US Department of Labor, Occupations Information for Bioengineers and Biomedical engineers. Available at: https://www.myskillsmyfuture.org/TargetOccupationMatch.aspx?onetcode $=17203100 \&$ detailonetco de $=17203100 \&$ keyword=biomedical\%20engineer \& highestmatch=Bioengineers+and+Biomedical+Engi neers\&zipcode $=0$ \&radius $=0 \&$ workPref $=0$ \&indgrou $\mathrm{p}=0$ \&indsize $=0$ \&Target Request $=\mathrm{T}$
26. National Society of Professional Engineers, Defining the Practice of Engineering. March 2018;1-3. Available at: https://www.nspe.org/sites/default/files/resources/ $\mathrm{pdfs} /$ admin/publications/NSPE-PE-Definitions.pdf

27.The National Society of Professional Engineers. The Professional Engineering. May 2007. Available at: https://www.nspe.org/sites/default/files/resources/ pdfs/pemagazine/june2007_the_professional_engineering.pdf

28. World Health Organization. Manpower Development for a Health Care Technical Service, A report of the World Health Organization International Meeting on Manpower Development and Training for Health Care Equipment Management, Maintenance, and Repair, WHO/ SHS/NHP/90.4, November 1989. Available at: https:// apps.who.int/iris/bitstream/handle/10665/62102/ WHO_SHS_NHP_90.4.pdf?sequence=1\&isAllowed=y

29. National Environmental Health Association (NEHA). Difference between Credentials and Certifications. Available at: https://www.neha.org/ professional-development/education-and-training/ differences-between-credentials-certifications

30.International Engineering Alliance. Graduate Attributes and Professional Competencies, Version 3; June 21, 2013. Available at: Graduate-Attributes-and-ProfessionalCompetencies.pdf (last visited May 26, 2021). 